\title{
Management of Symptoms of Allergic Rhinitis by Panchakarma Therapy: Concept and Application
}

\author{
Alka Mishra ${ }^{1}$, Lalima Batham ${ }^{1}$, Saurabh Mishra, ${ }^{2, *}$ \\ ${ }^{1}$ Department of Ayurveda and Holistic Health, Dev Sanskriti Vishwavidyalaya, Gayatrikunj- \\ Shantikunj, Haridwar, Uttarakhand, India \\ ${ }^{2}$ Dev Sanskriti Vishwavidyalaya, Gayatrikunj-Shantikunj, Haridwar, Uttarakhand, India
}

"Corresponding Author: Saurabh Mishra - Email: sau.dsvv@gmail.com

\section{Cite this research article as follows:}

Mishra A, Batham L, Mishra S. Management of symptoms of allergic rhinitis by panchakarma therapy: concept and application. Ayurveda evam Samagra Swasthya Shodhamala. 2019;1(1):4. [cited date]. Available from:

https://sites.google.com/dsvv.ac.in/shodhamala-dahh/asssm11/asssm114

\section{License information for readers:}

The original contents published in this research publication, which include research articles, case reports, etc., are published under the Creative Commons Attribution (CC BY 4.0) License. Anyone may reproduce, distribute, translate and create derivative works of this original content, subject to full attribution to the original research publication (Ayurveda evam Samagra Swasthya Shodhamala) and authors. The full terms of this license may be seen at https://creativecommons.org/licenses/by/4.0/

\section{Published by:}

Department of Ayurveda and Holistic Health

Dev Sanskriti Vishwavidyalaya

Gayatrikunj-Shantikunj, Haridwar - 249411

Uttarakhand, India

Email: dahh@dsvv.ac.in

Mobile: $+919258360953,+918954890390$

Website: http://www.dsvv.ac.in/dahh 


\begin{abstract}
Background: Allergic Rhinitis is an inflammatory disorder of the nasal mucosa; common symptoms include nasal congestion, sneezing, rhinorrhea, nose itching, etc. Effective management of this disease, in short duration of time, is still a challenge. As per the classical texts of Ayurveda, the disease that resembles the symptoms associated with allergic rhinitis is Vataja Pratishyaya; Nasya procedure of Panchakarma therapy has shown encouraging results in managing its symptoms.
\end{abstract}

Methodology: Panchakarma therapy was administered for 13 days to a male patient suffering from allergic rhinitis and associated ailments. According to Ayurveda, this disease is associated with the imbalance of Kapha and Vata doshas. Hence, Kapha and Vata pacifying therapeutic procedures and herbal medicines, that also provide nourishing effect to the respiratory system, were used. Later, patient took raw Haridra (Curcuma longa) for selfmanagement of disease at home.

Results: The patient experienced significant reduction in sneezing episodes, from about 150 per day to about 20 per day; relief in heaviness in the head region; and, complete relief in itching in nose and throat. Overall, the patient reported a good experience. In a followup taken after about one and a half years, the patient reported complete relief in sneezing episodes and heaviness in the throat, as well as non-recurrence of the earlier condition.

Conclusion: Panchakarma Therapy showed encouraging results with regards to the management of the symptoms associated with allergic rhinitis and associated ailments, in a short duration of time.

Keywords: Allergic Rhinitis, Vataja Pratishyaya, Panchakarma, Ayurveda, Nasya, Herbal Medicine 


\section{Introduction}

Allergic Rhinitis is an inflammatory disorder of the nasal mucosa caused by allergic sensitizaton to airborne allergens; it is characterized by nasal congestion, rhinorrhea, sneezing, itching of the nose and/or post-nasal discharge [1-10]. These symptoms often cause sleep disturbance, fatigue, depressed mood, etc., and thus have a major impact on the patient's quality of life and productivity [1-3,5,8-10]. Almost $20 \%-30 \%$ of the population is affected by this disease $[1,2,8,10]$.

Therapeutic interventions conventionally employed for relieving the symptoms associated with allergic rhinitis include allergen avoidance, oral antihistamines, intranasal corticosteroids, allergen immunotherapy, etc. [3,5,7-9]. Although these interventions are effective, yet there are various shortcomings such as occurrence of side-effects $[7,11,12]$, about $60 \%$ of the affected population not responding adequately to antihistamines and intranasal corticosteroids [5,10], etc. Hence, there is a definite need to look for other effective therapies for patients suffering from allergic rhinitis.

According to Ayurveda, a healthy human body is supposed to have a relatively stable equilibrium (congenial homeostasis) of Dosha (psycho-biological rhythm - Vata, Pitta, Kapha), Dhatu (body tissues and their nourishing elements) and Mala (excreta) [13,14]; Acharya Sushruta defines health as an equilibrium of Dosha (psycho-biological rhythm), Agni (digestion and metabolism), Dhatu (body tissues and their nourishing elements), Malakriya (excretory function), as well as the well being of soul, senses and mind $[13,14]$. Imbalance in this equilibrium leads to disease, and the aim of the therapy is to restore this balance [14]. Treatment of disease involves procedures for purifying the biological system by removing the vitiated elements from the entire body, and thus causing disease prevention, as well as health promotion [3,13-16].

As per the classical texts of Ayurveda, the disease that resembles the symptoms associated with Allergic Rhinitis is Vataja Pratishyaya [3,17,18]; these symptoms include Tanu Nasa Srava (rhinorrhea), Shirashoola (headache), Kshavathu (sneezing), etc. The concept of allergy is described under 'Asatmyaja Vyadhi', and its causes are hereditary, Viruddhahara (related with food allergens), Dushivisha (leading to blood vitiating disorders like Kitibha (psoriasis), etc.) and Ritu Sandhi (environmental factors, i.e. when proper seasonal regimen is not followed) [17,18]. Pratishyaya is described as one of the most important diseases related to nose (Nasaroga), wherein the vitiation of Vata and Kapha doshas at the root of the nose, produces a secretion that flows down through the nose [3]. Thus, Vataja Pratishyaya primarily involves the vitiation of the Vata and Kapha doshas.

According to Ayurveda, the treatment of Vataja Pratishyaya must simultaneously address the vitiation of both the Vata and Kapha doshas; shodhana (purificatory) and shamana (pacifying) therapies have been recommended in this regard [17]. Panchakarma is a purificatory Ayurvedic procedure, which includes Snehan (oleation) and Swedan (sudation) as Poorva Karma (pre-procedures); Vaman (therapeutic emesis), Virechan (therapeutic purgation), Anuvasana Basti (oil enema), Asthapana Basti (decoction enema) and Nasya (nasal insuffolation) as Pradhan Karma (main-procedure); and, Sansarjan Kram (graduated diet) as Paschat Karma (post-procedure) [19].

Nasya (nasal insuffolation) procedure of Panchakarma has been used for the treatment of Vataja Pratishyaya (Allergic Rhinitis) with encouraging results [3,17,18], wherein, Modha et al. (2009) [18] administered Shunthi Taila Nasya, along with internal drug Shuddha Haridra (purified Curcuma longa) to patients of allergic rhinitis; Bhakti et al. (2009) [17] administered Pippalyadi Taila Nasya, along with oral drug Haridra Khanda to patients of allergic rhinitis; and, Kumar et al. (2014) [3] administered Anu Taila Pratimarsha Nasya to patients of allergic rhinitis. Basti is another procedure of Panchakarma therapy, which is considered one of the best treatments for Vata related disorders [20]. Thus, Nasya and other 
procedures of Panchakarma therapy can be useful in the management of symptoms associated with allergic rhinitis.

A case report about a male patient, who was suffering from allergic rhinitis, as well as other associated ailments, is being presented here. He visited the Out Patient Section of the Department of Ayurveda and Holistic Health at Dev Sanskriti Vishwavidyalaya, Haridwar, and as is normally the case under most practical situations, he wanted relief in all the complaints in a limited time frame. In view of the above discussion, short term Panchakarma treatment was administered to the patient, and the effectiveness of the same is being presented in this article.

\section{Methods}

\subsection{Case Report}

A 36 year old male patient (height $157 \mathrm{~cm}$, weight $67 \mathrm{~kg}$ ) came to the Out Patient Section of the Department of Ayurveda and Holistic Health (DAHH) at Dev Sanskriti Vishwavidyalaya, Haridwar in August 2017. He had deviated nasal septum towards left side (DNS (L)). He had been advised Septoplasty, but he did not do it. He was suffering from symptoms of allergic rhinitis since about two years. The details of his medical history and the complaints at the time of the visit are as follows:

- Left nostril was partially blocked

- Sneezing episodes for up to 3 to 4 hours in the morning time - felt itching in the nose with multiple episodes of sneezing - about 150 to 200 sneezes every day

- Sometimes the sneezing continued the entire day

- Mucus used to stick in the throat; there was heaviness in the throat

- Severe heaviness in the head region

Pathological investigations (dated about two and half months prior to this visit) gave an AEC (Absolute Eosinophil Count) value of 630 cells $/ \mathrm{mm}^{3}$ and a DLC Eosinophils value of $7 \%$, both of which were above the normal range. The patient had no past history of diabetes mellitus, hypertension, ischemic heart disease, hypothyroidism.

Based on the above mentioned medical history and further discussion with the doctor, the diagnosis for the patient included deviated nasal septum towards left side, with Allergic Rhinitis, with Eosinophilia.

\subsection{Therapeutic Intervention}

As mentioned above, the patient was suffering from allergic rhinitis (Vataja Pratishyaya), which primarily involves the vitiation of the Vata and Kapha doshas. Furthermore, as the patient had come to the Out Patient Section, and had limited time to take the therapy, the therapeutic intervention was planned accordingly.

Informed consent was obtained from the patient before the start of the therapy.

The therapeutic intervention included Panchakarma therapy, which was administered to the patient for 13 days, and is listed in Table 1. Botanical names of medicinal plants used in the present study are given in Table 2 . 
Table 1: Therapeutic intervention administered to the patient over a period of 13 days. The letter ' $Y$ ' indicates that the therapeutic procedure mentioned in that row, was administered on that day.

\section{Therapeutic Intervention}

\section{Day}

Deepan Pachan Drug (Shankha Vati + Sitopaladi

Churna)

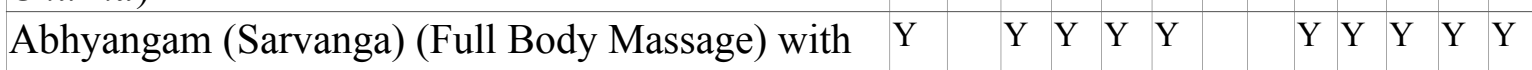

Sahacharadi Taila + Karpooradi Taila +

Dhanvantar Taila + Saindhav Lavan

Abhyangam (Ekanga) (Local Massage) of the above oils

Vashpa Sweda (Sarvanga) (Full Body Steam) of

Dashamoola kwatha and Erandamoola kwatha

Nadi Sweda (Local Steam) of Dashamoola kwatha and Erandamoola kwatha

Koshtha Shuddhi through Virechan Vati (Myrolax)

+ Avipattikar Churna

Basti - Anuvasana with Sahacharadi Taila

Basti - Asthapana with kwatha of Dashamoola +

Erandamoola + Triphala + Vasa + Kantakari +

Bharangi + Yashtimadhu + Bala + Giloy

Nasya with Shadbindu Taila (numbers represent the 6 number of drops in each nostril) (pre-procedure face Abhyangam with Karpooradi Taila)

Shirodhara with Til Taila

Kwatha of Dashamoola + Bala + Giloy + Nirgundi Y

\begin{tabular}{llll|ll|ll|l|l|l|l|l}
1 & 2 & 3 & 4 & 5 & 6 & 7 & 8 & 9 & 10 & 11 & 12 & 13
\end{tabular}

$\begin{array}{llllll}\mathrm{Y} & \mathrm{Y} & \mathrm{Y} & \mathrm{Y} & \mathrm{Y}\end{array}$

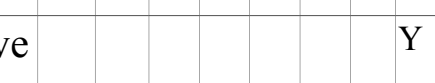

Y

+ Rasna + Nagarmotha + Vasa + Kantakari +

Bharangi + Yashtimadhu + Vacha (sweet) 
Table 2: Botanical names of medicinal plants used in the present study.

\begin{tabular}{|l|l|}
\hline Common Name & Botanical Name \\
\hline \multicolumn{2}{|l|}{ Dashamoola (Roots of ten plants) } \\
\hline (a) Laghu Panchamoola (roots / whole plant of 5 shrubs) \\
\hline Shalaparni & Desmodium gangeticum \\
\hline Prishnaparni & Uraria picta \\
\hline Brihati & Solanum indicum \\
\hline Kantakari & Solanum xanthocarpum \\
\hline Gokshuru & Tribulus terrestris \\
\hline (b) Brihat Panchamoola & roots of 5 trees) \\
\hline Bilva & Aegle marmelos \\
\hline Agnimanth & Clerodendrum phlomidis \\
\hline Gambhari & Gmelina arborea \\
\hline Shyonak & Oroxylum indicum \\
\hline Patala & Stereospermum suaveolens \\
\hline \multicolumn{2}{|l|}{} \\
\hline Triphala (combination & of 3 fruits) \\
\hline Amalki & Emblica officinalis \\
\hline Haritaki & Terminalia chebula \\
\hline Vibhitaki & Terminalia bellirica \\
\hline \multicolumn{2}{|l|}{} \\
\hline Bala & Sida cordifolia \\
\hline Bharangi & Clerodendrum Serratum \\
\hline Erandamoola & root of Ricinus communis \\
\hline Giloy & Tinospora cordifolia \\
\hline Nagarmotha & Cyperus rotundus \\
\hline Nirgundi & Vitex negundo \\
\hline Rasna & Pluchea lanceolata \\
\hline Vacha (sweet) & Acorus Calamus \\
\hline Vasa & Adhatoda vasica \\
\hline Yashtimadhu & \\
\hline
\end{tabular}

As shown in Table 1, the patient was given Deepan Pachan drugs on the first 5 days; Shankha Vati and Sitopaladi Churna were used. Ingredients of Sitopaladi Churna commonly include Saccharum officinarum (sugar candy), Bambusa arundinacea (siliceous concretion), Piper longum (dried fruit), Elettaria cardamomum (dried seed), and Cinnamonum zeylanicumm (stem bark) [21]. Ingredients of Shankha Vati commonly include Shankha bhasma (Conch Shell), Hingu (Ferula fietida Regel.), Vatsanabha (Aconitum Chasmantum Staff.ex. Holmes), Trikatu, Kshara, Lavana, etc. [22].

The snehan (oleation) therapies administered to the patient were as follows:

- Abhyangam (Sarvanga) (Full Body Massage) was given on day 1, from day 3 to day 6 , and from day 9 to day 13 
- Abhyangam (Ekanga) (gentle Local Massage) was given on day 8

Among the oils used for Abhyangam, the ingredients of Sahacharadi Taila commonly include Sahachara (Barleria prionits), Devadaru (Cedrus deodara) and Shunthi (Zingiber officinale Roscoe.) [23]; those of Karpooradi Taila commonly include Ajamoda (Trachyspermum ammi), Karpoor (Cinnamomum camphorum) and Coconut oil [24]; and, Dhanvantar Taila is a polyherbal formulation consisting of more than 40 ingredients, with Til Taila as base [25].

The snehan therapy was followed by swedan (sudation) therapy. The swedan therapies administered to the patient were as follows:

- Vashpa Sweda (Sarvanga) (Full Body Steam) was given on day 1, day 3 to day 6, and day 9 to day 13

- $\quad$ Nadi Sweda (Local Steam) was given on day 8

The snehan and swedan therapies are the purva karma (pre-procedures) for the Basti treatment as pradhan karma (main procedure).

Before starting the Basti treatment, Virechan vati - Myrolax tablet (Nagarjuna company) along with Avipattikar churna were given to the patient on day 7 for low-grade purification of gastro-intestinal tract (Koshtha Shuddhi). (Note: As Koshtha Shuddhi was done on day 7, hence full body massage was not done on the next day)

Basti treatment was given to the patient for five days, which included giving Anuvasana Basti (oil enema) and Asthapana Basti (decoction enema) on alternate days, i.e. Anuvasana Basti on days 9, 11 and 13, and Asthapana Basti on days 10 and 12. Anuvasana Basti [26] and Asthapana Basti [20] are the process of drug administration through the rectal route, wherein oil or other oleaginous substance is the major content in case of Anuvasana Basti, while medicated decoction is the major part in Asthapana Basti. Total of 3 Anuvasana and 2 Asthapana Basti were given to the patient.

Nasya (nasal insuffolation), with Shadbindu Taila (numbers given in Table 1 represent the number of drops in each nostril), was administered to the patient on day 1, from day 3 to day 6 , and from day 8 to day 10 . The pre-procedure (purva karma) of Nasya involves doing massage (abhyangam) and hot fomentation (swedan) on the face and head [27-29]. This is followed by the main-procedure (pradhan karma) of Nasya, wherein the medicine is administered through the nasal route by pouring it, drop by drop, in both the nostrils [28]. Shadbindu Taila commonly includes Til Taila (Sesamum indicum L.), Bhringa (Eclipta alba (L.) Hassk.), Aja Paya (goat milk), Eranda (Ricinus communis L.), Tagara (Valeriana wallichii DC.), Shatahva (Anethum sowa Roxb.), Jivanti (Leptadenia reticulata [Retz.] Wight and Arn.), Rasna (Pluchea lanceolata), Vidanga (Embelia ribes Burm.f.), Yashti (Glycyrrhiza glabra L.), Shunthi (Zingiber officinale Roscoe.), and Saindhava Lavana (Rock salt) [30].

Shirodhara of Til Taila was administered to the patient on the last three days of the therapy. The procedure of Shirodhara involves continuous pouring of medicated liquid on the forehead of the patient, which creates specific pressure and vibration on the forehead $[31,32]$.

The patient was also given a Kwatha (decoction) of Vata pacifying (Vata-shamak) and tissue nourishing (Vrinhan) herbal medicines on all the days of the therapy except day 2 and day 7.

Some other associated methodologies that were administered along with the above therapeutic procedure are as follows.

Dietary restrictions were prescribed, which included not taking Vata and Kapha aggravating diet. It was advised to take only warm water to drink, and for bathing etc. Other 
behavioral regimen were also prescribed, such as, do not indulge in fear, anxiety, stress, anger, and any other negative thought; do not roam around too much; do not obstruct your natural urges like hunger, thirst, sleep, yawning, tear, etc. Try to keep your mind calm and happy, try to be silent, go early to bed and wake up early in the morning.

The doctor regularly talked to the patient about his condition, and provided both clinical and motivational guidance, i.e. did regular counseling with positive thoughts. Gayatri Mantra was played continuously during the therapy.

\section{Results}

In this case report, the outcomes were assessed in a qualitative (subjective) manner based on the doctor's pre and post examination, and, patient's experiential feedback, as given in Table 3.

Table 3: Pre Therapy and Post Therapy Observations

\begin{tabular}{|l|l|}
\hline Pre Therapy Observation & Post Therapy Observation \\
\hline Severe heaviness in the head region & $90 \%$ improvement \\
\hline $\begin{array}{l}\text { Sneezing episodes for up to } 3 \text { to } 4 \text { hours in the } \\
\text { morning time - about } 150 \text { to } 200 \text { sneezes every } \\
\text { day - sometimes sneezing continued the entire day }\end{array}$ & $\begin{array}{l}\text { Significant reduction in sneezing episodes - } \\
\text { only about } 15 \text { to } 20 \text { sneezes in the entire day - } \\
\text { no problem in the morning time }\end{array}$ \\
\hline $\begin{array}{l}\text { Severe itching present in the nose and throat } \\
\text { region }\end{array}$ & $\begin{array}{l}100 \% \text { improvement in the itching } \\
\text { Heaviness in the throat still present }\end{array}$ \\
\hline Left nostril partially blocked & $\begin{array}{l}\text { During breathing, there was difficulty in taking } \\
\text { breath from left side }\end{array}$ \\
\hline & $\begin{array}{l}\text { Overall, the patient had a good experience after } \\
\text { taking the therapy }\end{array}$ \\
\hline
\end{tabular}

Before the start of the therapy the patient reported severe heaviness in the head region. After 13 days of the Panchakarma treatment, the patient reported about $90 \%$ improvement in this complaint.

Before the start of the therapy, the patient reported sneezing episodes for up to 3 to 4 hours in the morning time, with about 150 to 200 sneezes every day, and sometimes sneezing continued the entire day. After the therapy, the patient reported significant reduction in sneezing episodes, with only about 15 to 20 sneezes in the entire day, and no problem in the morning time.

Before the start of the therapy, the patient reported the presence of severe itching in the nose and throat region. After the therapy, there was complete relief in itching, but heaviness in the throat was still present.

Before the start of the therapy, the left nostril was partially blocked due to DNS. The patient continued to experience difficulty in taking breath from left nostril after the therapy.

Overall, the patient reported a good experience after taking the therapy.

\subsection{Followup}

About one and a half years after taking the Panchakarma therapy, a verbal feedback 
was taken from the patient over telephone, in March 2019, regarding his current condition. The patient reported that he was doing well and did not experience a recurrence of his earlier condition. There was complete relief in sneezing episodes and heaviness in the throat. All this while, he had been taking raw Haridra (Curcuma longa) as supportive care.

\section{Discussion}

A case report about a male patient, who was suffering from allergic rhinitis, as well as other associated ailments, is being presented here. Since allergic rhinitis (Vataja Pratishyaya) is primarily associated with the vitiation of the Vata and Kapha doshas, Panchakarma therapy was administered to the patient accordingly.

The results given in Table 3 indicate that Panchakarma Therapy gives encouraging outcomes, even in short duration. This result may be attributed to the therapeutic action of various Ayurvedic procedures administered to the patient.

To begin with, Deepan Pachan medicines are administered for enhancing the digestive fire [33,34], for digestion of the Ama Dosha (undigested toxins of the body that are responsible for the blockage of micro-channels, i.e. srotas), as well as for the preparation of the body for next therapies. Shankha Vati is beneficial in digestion [22]. The ingredients of Sitopaladi Churna also have Kapha pacifying properties [35,36].

The snehan (oleation) (Abhyangam - massage) and swedan (sudation) (Vashpa Sweda steam) therapies are the purva karma (pre-procedures) for the pradhan karma (main procedures) described above; these cause softening and liquifying of the vitiated Doshas [27], which can then be removed from the body through the pradhan karma (main procedure).

The oils used in snehan therapy have snigdha (unctuous), guru (heavy) and mridu (soft) properties, which are opposite to the properties of Vata; hence Abhyangam reduces the vitiated Vata [37]. Also, in the present study, the oils and other ingredients chosen for Abhyangam were such, which balance the Kapha dosha as well; Saindhav Lavan has Kapha pacifying properties [35,36], ingredients of Dhanvantar Taila have Vata pacifying properties [25,35,36,38], and, ingredients of Sahacharadi Taila [39] and Karpooradi Taila [35,36] have both Kapha and Vata pacifying properties. Besides balancing the vitiated Doshas, the oils also provide nourishing effect (Vrinhan) to the degenerative tissues.

Swedan has actions like stambhaghna (relieves stiffness), sweda-karak (creates perspiration), and, gauravaghna (cures heaviness) [37].

Nasya (nasal insuffolation) was administered to the patient with Shadbindu Taila. The pre-procedure (purva karma) of Nasya (massage and hot fomentation on the face and head) causes the softening and liquifying of the vitiated Doshas [27-29]. The vasodilation caused by the pre-procedure is supposed to increase the permeability of the blood vessels, which makes the absorption of the medicine faster [27]. The main-procedure (pradhan karma) of Nasya involves administering the medicine through the nasal route, by pouring it, drop by drop, in both the nostrils [28].

Nasya primarily affects the urdhvajatrugata pradesha (supra-clavicular region) [28,38]. According to Acharya Vagbhatta, nose is one of the most convenient routes to convey medicinal effects to the cranial cavity [28]. According to Acharya Charaka, nasya drug usually acts through absorption by the Shringataka marma (a vital spot in the head region situated at the site of the union of the nerves, supplying to the nose, ears, eyes, and tongue); after absorption, the medicine acts on the diseases of the respiratory system, shoulder, neck, etc., and the vitiated Doshas are expelled from the head region [28]. Thus, the administered medicine moves up to the Shringataka marma, spreads all over the head, channels of eyes, ears, nose and throat, and removes vitiated Doshas from there [28,38].

Nasya was done with Shadbindu Taila, whose ingredients have beneficial effects with 
regards to balancing the vitiated Vata and Kapha doshas, as well as providing strength and nourishing effect (Vrinhan) to the respiratory system [35,36]; Rasna has Vata pacifying and rejuvenating properties [35,36], Shunthi has Kapha and Vata pacifying properties [18], Saindhav Lavan has Kapha pacifying properties [35,36].

The Koshtha Shuddhi procedure does a low-grade purification of the gastro-intestinal tract, and prepares the body for the Basti treatment.

Basti is one of the best treatment in the case of Vata disorders [20], as stated by Acharya Charak (Vastirvaataharaannaam) \{Charak Samhita - Sutra Sthan 25/40\} [15,16]. During the treatment, 3 Anuvasana Basti (oil enema), and 2 Asthapana Basti (decoction enema) were administered to the patient. Anuvasana Basti (oil enema) nourishes the dhatus, promotes strength and cures Vata related diseases; Asthapana Basti (decoction enema) cleanses the colon and cures Vata related diseases [37]. Also, the herbal medicines used for Basti in the present study, have Kapha pacifying properties as well [35,36]; hence, Basti must have helped in balancing both the vitiated Vata and Kapha Doshas.

Since the patient reported severe heaviness in the head region, hence Shirodhara was administered to the patient. Shirodhara creates specific pressure and vibration on the forehead, with beneficial therapeutic effect in terms of relieving stress, anxiety, etc. [31,32]. The Til Taila used for Shirodhara has Vata pacifying properties [31].

The patient was also given a Kwatha (decoction) of Kapha and Vata pacifying, as well as tissue nourishing (Vrinhan) herbs [35,36], which must have contributed to the observed therapeutic benefits.

Almost daily the doctor talked to the patient about his condition, and provided both clinical and motivational guidance; the purpose was to instill confidence in the patient that his condition can be improved, and he has to himself take responsibility of bringing about this change by diligently following the prescribed treatment and guidelines.

Gayatri Mantra was played continuously during the therapy; Gayatri Mantra causes beneficial effects with regards to various physical and mental conditions like attention, concentration, etc. [40-45]. The patient must also have benefited from the spiritually charged environment of Dev Sanskriti Vishwavidyalaya, Haridwar.

During Panchakarma Therapy, it is advised to avoid 'Ashta-Maha-Doshkar-Bhav' (eight types of behavioral and dietetic practices that cause obstructions in micro-channels (srotas) leading to aggravation of the diseases) so that better results can be observed. The following of these practices must also have contributed in providing the observed relief.

The above discussion reveals that since the major complaints of the patient were associated with Kapha and Vata imbalance, hence, the therapeutic procedures administered to the patient had Kapha and Vata pacifying, as well as tissue nourishing (Vrinhan) effects, which must have caused the amount of relief experienced by the patient in such a short duration of therapy. Also, in place of using a single therapy, a combination of different therapeutic procedures, along with multiple herbs, were used, in order to achieve simultaneous management of the symptoms associated with multiple ailments.

Although the results are qualitative in nature, yet the degree of benefit attained in simultaneously addressing multiple complaints is noteworthy, especially considering the fact that the patient was an Outdoor Patient, had genuine limitations in following the dietary restrictions, and the therapy was administered for quite short duration.

With regards to the long term impact of the therapeutic procedure, in a followup taken about one and a half years after taking the above therapeutic procedure, the patient reported that he was doing well and did not experience a recurrence of his earlier condition. There was complete relief in sneezing episodes and heaviness in the throat. All this while, he had been taking raw Haridra (Curcuma longa) as supportive care, which has blood purifying properties, and is also Kapha and Vata Shamaka (pacifying) [18]. This long-term non- 
recurrence of the disease symptoms after the above therapeutic procedure is an extremely encouraging outcome, and illustrates the effectiveness of this therapeutic procedure in longterm management of the symptoms associated with allergic rhinitis and associated ailments.

Further in-depth quantitative study would definitely be worthwhile to establish the mode of operation of the administered therapeutic procedure in the light of modern scientific understanding.

\section{Conclusion}

Panchakarma Therapy was administered to a male patient for the management of the symptoms associated with allergic rhinitis and associated ailments. Various therapeutic procedures were administered to the Out Patient section patient over a period of 13 days. Qualitative analysis showed encouraging results, with the patient experiencing relief in various symptoms including sneezing episodes, heaviness in the head region, and, itching in the nose and throat region, in a short duration of time. The long term effects of the therapeutic procedure were also found to be encouraging with the patient reporting complete relief in sneezing episodes and heaviness in the throat, as well as non-recurrence of the earlier condition, after about one and a half years of taking the therapy (the patient took raw Haridra (Curcuma longa) as supportive care during this time).

\section{Acknowledgements}

Authors would like to acknowledge the subtle guidance of their spiritual guide, Revered Pandit Shriram Sharma Acharya, who founded the organization All World Gayatri Pariwar (www.awgp.org). The authors thank the faculty and staff of the Department of Ayurveda and Holistic Health and the Department of Complementary and Alternative Medicine at Dev Sanskriti Vishwavidyalaya, Haridwar for their support in conducting this study.

Compliance with ethical standards: Informed consent was obtained from the patient before the start of the therapy.

Conflict of interest: The authors declare that they have no conflict of interest.

\section{References}

1. Amritwar AU, Lowry CA, Brenner LA, Hoisington AJ, Hamilton R, Stiller JW, et al. Mental health in allergic rhinitis: depression and suicidal behavior. Current Treatment Options in Allergy. 2017; 4(1): 71-97.

(https://www.ncbi.nlm.nih.gov/pmc/articles/PMC5614510/)

2. Hoyte FCL, Nelson HS. Recent advances in allergic rhinitis [version 1; referees: 2 approved]. F1000Research. 2018; 7(F1000 Faculty Rev): 1333. doi: 10.12688/f1000research.15367.1.

(https://www.ncbi.nlm.nih.gov/pmc/articles/PMC6107993/) 
3. Kumar S, Debnath P, Banerjee S, GR AR, Rao PN. Clinical investigations on the ayurvedic management of allergic rhinitis (vataja pratishyaya) by pratimarsha nasyaas nasal drug delivery system. Exploratory Animal and Medical Research. 2014; 4(2): 194-205.

(http://www.animalmedicalresearch.org/Vol.4_Issue-2_December_2014/Shiva \%20kumar.pdf)

4. Kozlov V, Lavrenova G, Savlevich E, Bazarkina K. Evidence-based phytotherapy in allergic rhinitis. Clinical Phytoscience. 2018; 4: 23. doi: 10.1186/s40816-018-0080-0. (https://clinphytoscience.springeropen.com/articles/10.1186/s40816-018-0080-0)

5. Scadding GW, Calderon MA, Shamji MH, Eifan AO, Penagos M, Dumitru F, et al. Effect of two years of treatment with sublingual grass pollen immunotherapy on nasal response to allergen challenge at three years among patients with moderate to severe seasonal allergic rhinitis: a randomized clinical trial: the grass randomized clinical trial. Journal of the American Medical Association. 2017; 317(6): 615-625. doi: 10.1001/jama.2016.21040. (https:/www.ncbi.nlm.nih.gov/pmc/articles/PMC5479315/)

6. Sinha B, Vibha, Singla R, Chowdhury R. Allergic rhinitis: a neglected disease - a community based assessment among adults in delhi. Journal of Postgraduate Medicine. 2015; 61(3): 169-175. doi: 10.4103/0022-3859.159418. (https://www.ncbi.nlm.nih.gov/pmc/articles/PMC4943409/)

7. Small P, Keith PK, Kim H. Allergic rhinitis. Allergy, Asthma \& Clinical Immunology. 2018; 14(Suppl 2): 51. doi: 10.1186/s13223-018-0280-7. (https://www.ncbi.nlm.nih.gov/pmc/articles/PMC6156899/)

8. Varshney J, Varshney H. Allergic rhinitis: an overview. Indian Journal of Otolaryngology and Head and Neck Surgery. 2015; 67(2): 143-149. doi: 10.1007/s12070-015-0828-5. (https://www.ncbi.nlm.nih.gov/pmc/articles/PMC4460099/)

9. Wheatley LM, Togias A. Allergic rhinitis. The New England Journal of Medicine. 2015; 372(5): 456-463. doi: 10.1056/NEJMcp1412282. (https://www.ncbi.nlm.nih.gov/pmc/articles/PMC4324099/)

10. Zajac AE, Adams AS, Turner JH. A systematic review and meta-analysis of probiotics for the treatment of allergic rhinitis. International Forum of Allergy \& Rhinology. 2015; 5(6): 524-532. doi: 10.1002/alr.21492.

(https://www.ncbi.nlm.nih.gov/pmc/articles/PMC4725706/)

11. Cheng L, Chen J, Fu Q, He S, Li H, Liu Z, et al. Chinese society of allergy guidelines for diagnosis and treatment of allergic rhinitis. Allergy, Asthma \& Immunology Research. 2018; 10(4): 300-353. doi: 10.4168/aair.2018.10.4.300. (https://www.ncbi.nlm.nih.gov/pmc/articles/PMC6021586/)

12. Werkhäuser N, Bilstein A, Sonnemann U. Treatment of allergic rhinitis with ectoine containing nasal spray and eye drops in comparison with azelastine containing nasal spray and eye drops or with cromoglycic acid containing nasal spray. Journal of Allergy. 2014; 2014: 176597. doi: 10.1155/2014/176597. (https://www.ncbi.nlm.nih.gov/pmc/articles/PMC4058592/)

13. Kadlimatti SM, Maheshwari KS, Chandola HM. Critical analysis of the concept of asthi kshaya vis-a-vis osteoporosis. Ayu. 2009; 30(4): 447-458. (http://www.ayujournal.org/temp/Ayu304447-2819005_074950.pdf)

14. Murthy KRS. Susruta samhita - vol. I, II, III. Varanasi, Uttar Pradesh, India: Chaukhambha Orientalia; 2008.

15. Shastri K, Chaturvedi GN. Charak samhita - elaborated vidyotini hindi commentary. PartI. Varanasi, Uttar Pradesh, India: Chaukhamba Bharati Academy; 2001.

16. Shastri K, Chaturvedi GN. Charak samhita - elaborated vidyotini hindi commentary. PartII. Varanasi, Uttar Pradesh, India: Chaukhamba Bharati Academy; 2003. 
17. Bhakti C, Rajagopala M, Shah AK, Bavalatti N. A clinical evaluation of haridra khanda \& pippalyadi taila nasya on pratishyaya (allergic rhinitis). Ayu. 2009; 30(2): 188-193.

(http://www.ayujournal.org/article.asp?issn=0974-

8520; year $=2009$; volume $=30 ;$ issue $=2 ;$ spage $=188$; epage $=193$; aulast $=$ Bhakti;type $=0$ )

18. Modha NJ (Tank), Shukla VD, Baghel MS. Clinical study of anurjata janita pratishyaya (allergic rhinitis) \& comparative assessment of nasya karma. Ayu. 2009; 30(1): 47-54.

(http://www.ayujournal.org/article.asp?issn=0974-

8520; year $=2009$; volume $=30$; issue $=1$; spage $=47$; epage $=54$; aulast $=$ Modha;type $=0$ )

19. Yadaiah P. Clinical panchakarma. Akola, Maharashtra, India: Jaya Publications; 2008.

20. Gundeti MS, Raut AA, Kamat NM. Basti: does the equipment and method of administration matter? Journal of Ayurveda and Integrative Medicine. 2013; 4(1): 9-12. (https://www.ncbi.nlm.nih.gov/pmc/articles/PMC3667437/)

21. Makhija IK, Ram HNA, Shreedhara CS, Kumar VS, Devkar R. In vitro antioxidant studies of sitopaladi churna, a polyherbal ayurvedic formulation. Free Radicals and Antioxidants. 2011; 1(2): 37-41. (http://phcogfirst.com/article/730)

22. Kodlady N, Patgiri BJ. Varieties in shankha vati - an ayurvedic classical formulation for GIT disorders. Annals of Ayurvedic Medicine. 2012; 1(3): 102-108. (https://www.aamjournal.in/?mno=17697)

23. Nair PR, Vijayan NP, Madhavikutty P, Nair CNB, Chandrika A. Clinical evaluation of sahacharadi and nirgundi tailas in saisaveeyavata (poliomyelitis). Ancient Science of Life. 1988; VIII(1): 25-29. (https://www.ncbi.nlm.nih.gov/pmc/articles/PMC3331345/)

24. Hepsibah PTA, Prasad NBR, Kumar PS. Standardisation of ayurvedic oils. Ancient Science of Life. 1998; 17(4): 280-283.

(https://www.ncbi.nlm.nih.gov/pmc/articles/PMC3331126/)

25. Lakshmi C. Allergic contact dermatitis (type IV hypersensitivity) and type I hypersensitivity following aromatherapy with ayurvedic oils (dhanwantharam thailam, eladi coconut oil) presenting as generalized erythema and pruritus with flexural eczema. Indian Journal of Dermatology. 2014; 59(3): 283-286. doi: 10.4103/0019-5154.131402. (https://www.ncbi.nlm.nih.gov/pmc/articles/PMC4037951/)

26. Kadus PA, Vedpathak SM. Anuvasan basti in escalating dose is an alternative for snehapana before vamana and virechana: trends from a pilot study. Journal of Ayurveda and Integrative Medicine. 2014; 5(4): 246-250.

(https://www.ncbi.nlm.nih.gov/pmc/articles/PMC4296438/)

27. Chaudhari V, Rajagopala M, Mistry S, Vaghela DB. Role of pradhamana nasya and trayodashanga kwatha in the management of dushta pratishyaya with special reference to chronic sinusitis. Ayu. 2010; 31(3): 325-331.

(https://www.ncbi.nlm.nih.gov/pmc/articles/PMC3221066/)

28. Das B, Ganesh RM, Mishra PK, Bhuyan G. A study on apabahuka (frozen shoulder) and its management by laghumasha taila nasya. Ayu. 2010; 31(4): 488-494.

(https://www.ncbi.nlm.nih.gov/pmc/articles/PMC3202264/)

29. Gupta DP, Rajagopala M, Dhiman KS. A clinical study on Akshitarpana and combination of akshitarpana with nasya therapy in timira with special reference to myopia. Ayu. 2010; 31(4): 473-477. (https://www.ncbi.nlm.nih.gov/pmc/articles/PMC3202262/)

30. Shailajan S, Menon SN, Tiwari BR, Singh AS. Standardization of shadbindu taila: an ayurvedic oil based medicine. Ayu. 2013; 34(1): 103-107.

(https://www.ncbi.nlm.nih.gov/pmc/articles/PMC3764865/)

31. Kundu C, Shukla VD, Santwani MA, Bhatt NN. The role of psychic factors in pathogenesis of essential hypertension and its management by shirodhara and sarpagandha vati. Ayu. 2010; 31(4): 436-441.

(https://www.ncbi.nlm.nih.gov/pmc/articles/PMC3202255/) 
32. Pokharel S, Sharma AK. Evaluation of insomrid tablet and shirodhara in the management of anidra (insomnia). Ayu. 2010; 31(1): 40-47.

(https://www.ncbi.nlm.nih.gov/pmc/articles/PMC3215320/)

33. Dudhamal TS, Gupta SK, Bhuyan C, Singh K. The role of apamarga kshara in the treatment of arsha. Ayu. 2010; 31(2): 232-235.

(https://www.ncbi.nlm.nih.gov/pmc/articles/PMC3215370/)

34. Lekurwale PS, Pandey K, Yadaiah P. Management of amavata with 'amrita ghrita': a clinical study. Ayu. 2010; 31(4): 430-435.

(https://www.ncbi.nlm.nih.gov/pmc/articles/PMC3202259/)

35. Sharma PV. Dravyaguna vijnana - volume II (vegetable drugs) (Hindi). Varanasi, Uttar Pradesh, India: Chaukhambha Bharati Academy; 2001.

36. Misra B, Vaisya R. Bhavaprakasa of shri bhava misra (including bhavaprakasa nighantu portion) - edited with the 'vidyotini' hindi commentary, notes and appendix - first part. Varanasi, Uttar Pradesh, India: Chaukhambha Sanskrit Bhawan; 2013.

37. Sharma MR, Mehta CR, Shukla DJ, Patel KB, Patel MV. Multimodal ayurvedic management for sandhigata vata (osteoarthritis of knee joint). Ayu. 2013; 34(1): 49-55. (https://www.ncbi.nlm.nih.gov/pmc/articles/PMC3764880/)

38. Radhika C, Kumar GV, Mihirjan K. A randomized controlled clinical trial to assess the efficacy of Nasya in reducing the signs and symptoms of cervical spondylosis. Ayu. 2012; 33(1): 73-77. (https://www.ncbi.nlm.nih.gov/pmc/articles/PMC3456869/)

39. Shantha TR, Pattanshetty JK, Gopakumar K. Pharmacognostical studies on the root of sahachara nilgirianthus heyneanus (nees) bremek - (acanthaceae). Ancient Science of Life. 1988; VII(3\&4): 139-144.

(https://www.ncbi.nlm.nih.gov/pmc/articles/PMC3336645/)

40. Brahmavarchas. Yagya - ek samagra upachar prakriya (Hindi). Pandit Shriram Sharma Acharya samagra vangamaya. volume 26. revised ed. Mathura, Uttar Pradesh, India: Akhand Jyoti Sansthan; 2012.

41. Brahmavarchas. Shabda brahma - nad brahma (Hindi). Pandit Shriram Sharma Acharya samagra vangamaya. volume 19. 2nd ed. Mathura, Uttar Pradesh, India: Akhand Jyoti Sansthan; 2012.

42. Malhotra V, Goel N, Dhar U, Garg R, Tripathi Y. Comparison of mind control techniques: an assessment of reaction times. Bangladesh Journal of Medical Science. 2016; 15(4): 596-600. (https://www.banglajol.info/index.php/BJMS/article/view/30718)

43. Pradhan B, Derle SG. Comparison of effect of gayatri mantra and poem chanting on digit letter substitution task. Ancient Science of Life. 2012; 32(2): 89-92. (https://www.ncbi.nlm.nih.gov/pmc/articles/PMC3807963/)

44. Sharma S. Super science of gayatri. revised ed. translation by Pandya SN, Shambhudas. Mathura, Uttar Pradesh, India: Yug Nirman Yojana Vistar Trust, Gayatri Tapobhumi; 2010. (http://literature.awgp.org/book/Super_Science_of_Gayatri/v1.1)

45. Sharma S. Gayatri mahavigyan - sanyukta sanskaran (Hindi). revised ed. Mathura, Uttar Pradesh, India: Yug Nirman Yojana Vistar Trust, Gayatri Tapobhumi; 2010. (http://literature.awgp.org/book/Super_Science_of_Gayatri/v2) 